\title{
The Pattern Of Collaboration For Encouraged Sustainability And Management Of Ethnic Community In Forest Land And Rural Development In Thailand
}

Prasit Kunurat, Mahasarakham University, Thailand

Preecha Piampongsarn, Chulalongkorn University, Thailand

Preecha Prathepa, Mahasarakham University, Thailand

Boonyong Ketkong, Mahasarakham University, Thailand

\begin{abstract}
This research focuses on factors that influence conflict over land-use patterns in ethnic communities in Phu Phan National Park in the northeast area of Thailand. The purposes of this study were: 1) to examine land use in local communities, 2) to explore the pattern of collaboration for encouraging the sustainability of community management in a forested area, and 3) to set up public policy for the management of land use in forested areas. For this research, we collected and analyzed qualitative and quantitative data. We administered 571 questionnaires to study typical land use, and a mixed methods approach was used to gather data. We found that two categories affect communities' land use management: 1) social and cultural factors, or ecoculture, and 2) state policy and market accessibility. There are three patterns for management: 1) thinking system, 2) production pattern, and 3) land use. In addition, we also stated the public policies regarding management of the forest, which include 1) a policy of ecology management, 2) a knowledge sharing policy, 3) a policy for the management of the river basin, and 4) a decentralization policy.
\end{abstract}

Keywords: Sustainability, Forest Land, Ethnic community, Rural Development, Thailand

\section{INTRODUCTION}

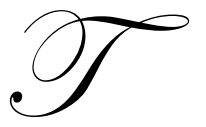

he global environment has numerous problems as a result of rapid industrial and technological developments, high population growth and unsustainable exploitation of resources. While forests are essential parts of the planetary ecosystem, they are among the natural habitats that are most exploited by human activities and industrialization. This is especially true of countries in economic transition, like Thailand. To organize and structure protection and management, forest management coordinates the expectations and demands of multiple social sectors. Although the importance of soil spatial heterogeneity has been recognized, its extent is still poorly understood and documented for many landscape positions (Gallardo, 2003).

Landscape position influences primary productivity and vegetation type due to its effects on incoming solar energy, soil stability, water regime and nutrient supply. In forest ecosystems, variable productivity with topographic differences has often been related to differences in soil properties (Arrouays et al., 1998). However, because a variety of factors affect growth, productivity and landscape position are not always directly associated (Hairston and Grigal, 1991). Landscapes have dramatically changed in the countryside as a result of both public subsidies and technological changes in agriculture and forestry (Bush, 2006; Westhoek et al, 2006). These changes have brought about a decline in the traditional roles of agriculture and an increased interest in new functions (De Groot, 2006). In addition, different agro-ecosystems have different capabilities of shaping the landscape, and rural landscapes will 
display a different degree of the agricultural component, depending on the composition of the agricultural systems (Kline and Wichelns, 1996; Mottet et al., 2006).

Thailand has a land area of $514,000 \mathrm{~km}^{2}$ and a population of over 50 million, with almost 40 million people living in rural areas. One-fifth of the people live on land classified as forest. In 1943, forests covered 63 percent of the country, but rapid deforestation has now cut this figure in half, reducing forests to only about 30 percent, or 15.6 million ha. There are 45 national parks and 47 forest parks covering 2.0 million ha, while wildlife sanctuaries occupy 1.85 million ha. In addition, all forests, except for some strips of coastal mangrove, are owned by the government and are under the control of the Royal Forest Department established in 1896 and, since 1925, a division of the Ministry of Agriculture. Technically, the Royal Forest Department has jurisdiction over approximately 25.6 million ha. It is headed by a director-general in charge of 21 divisions and 634 local forestry offices with a permanent staff of over 9,000, of whom 6,800 are professional or semi-professional foresters (Haque, 1985).

In Thailand, forest area has decreased dramatically during the last 30 years. A total logging ban issued in 1989 slowed deforestation, but logging could not be stopped entirely. Thailand has been trying to find new ways of forest management to deal with the danger of forest loss and degradation. Community forests are one solution discussed in the Thai public and in Thai forestry. Participation of local residents in the management of forest resources seems to be a promising way to conserve remaining forest areas. A growing number of villages have been managing their own forest land as community forests. NGOs working in rural development and conservation, scientists, and the Royal Forest Department have been drafting a community forestry bill. The recent change in government delayed the passage of the law, leaving community forests without a legal basis for their existence (KeBler, 1998).

The northeast region of Thailand, occupying a landmass of $168,000 . \mathrm{km}^{2}$, accounts for roughly one-third (32.8 per cent) of Thailand's total land mass. The area in this region is, on average, 122 to 183 meters above sea level (Myers, 2005). It is located on the Khorat Plateau and a few low hills, bordered by the Mekong River to the north and east, and by Cambodia to the south. To the west it is separated from northern and central Thailand by the Phetchabun mountain range. The plateau consists of two main plains: 1) the southern Khorat plain is drained by the Mun and Chi rivers and 2) the northern Sakon Nakhon plain is drained by the Loei and Songkhram rivers. The two plains are separated by the Phu Phan mountains. Improved income from commercial agriculture has revived the economy of the northeast. Commercial agriculture has raised the standard of living, but in relative terms, the northeast population is still lagging behind its counterparts in other regions. Without development in the farm sector during the last four decades, the standard of living would be much worse. Poverty in the region is rapidly declining. The commercialization of agriculture over the past four decades has brought many benefits. The farming population is now more acquainted with commercialization and the use of new technology. They have become politically empowered through more active engagement in policy dialogues that affect them directly. The use of farm machinery has eased farmers' work loads and many farmers find more time for off-farm and non-farm employment.

Forests are being rapidly depleted in the region, although population growth, logging concessions, poverty, and road density were contributing factors. The rate of decrease has slowed down in the last decade as the population growth rate decreased. While there are concerns about soil erosion, salinity and loss of fertility as a result of expanding areas of cassava, sugar cane, and maize; much of the evidence is site-specific. More scientific studies are needed to confirm some of these negative environmental effects. In some cases, a natural deterioration affects society, which is caused by a change in land-use patterns - soil, water, forest, and other resources - through many activities conducted without any attempt to protect the land. In addition, various activities, such as agricultural parks, forest farming, use of mixed agricultural methods, natural agriculture, and community forests, are affecting the sustainability of the ecological system. For example, before 1998, the Phu Phan range in the Sakhon Nakorn and Mookdaharn provinces was losing approximately 444.50 and 833.44 square kilometers each year, respectively.

Moreover, migratory movement and desertification of forest communities, as a result of degenerated forests, have begun to occur in many locations. This trend means that if forests, soil, basins, and rivers continue to be without management, the natural resources will be destroyed (Rojanapraiwong, 1999: 143). In addition, the 
central government still manages this issue without cooperation from local communities, never asking them about what the real situation is in their areas or what it is they want.

To solve the problem of natural resources management, local communities need to have social power and efficient guidance from the government. They also need wider collaboration between government agencies and local communities in forested areas (Ganjanapan, 2000). As mentioned above, many questions have arisen:

1. What factors influence land use management?

2. What is a useful pattern of collaboration for sustainable community management in forested areas?

3. What is the best public policy to encourage the management of local communities in forested areas?

are:

The answers to these questions are not clear as yet, but all must be answered. The objectives of this study

1. to study the factors that influence land use management in local communities,

2. to explore the pattern of collaboration for sustainable community management in forested areas, and

3. to set up public policy for the management of land use in forested areas.

Our discussion and recommendations will also benefit the management of forested areas in rural communities in Thailand and in other developing countries.

\section{RESEARCH METHODOLOGY}

In this research, we use both qualitative and quantitative methods. In the qualitative method, we spent three years (2005-2007) on observation, community interviews, and in-depth interviews. We worked with three up-hill forest communities: 1) Thai-Lao, 2) Phu-Thai, and 3) Bru - all within range of the Phu Phan National Park in northeast Thailand.

The sample was selected by purposive sampling with the three case studies in the Phu Phan National Park: 1) Thai-Lao (Sangkaew Village), 2) Phu Thai (Nongwaeng Village), and 3) Bru (Pungdaeng village) in Mookdaharn province. The qualitative data have described the problem of community, collaborative relationships and conflict of land use.

We administered 571 questionnaires to 571 families in the three communities. SPSS for Windows (Statistical Package for Social Science) was used to analyze in quantitative method.

\section{RESULTS OF ANALYSIS}

We administered 171 questionnaires to Pungdaeng village, 200 to Nongwaeng village, and 200 to Sangkaew village to study land use.

In the qualitative method, we divided the dynamics of land use and management into three periods:

1. Land reservation for settlement period (Pre-1966): The community cut forests and established villages in the middle of the forest near water; however, geomorphology and geo-ecology of the forest are different. The Phu Thai community settled at the foot of the hill; the Thai-Lao community settled high up in the mountains; and the Bru community settled in a far-away gorge with a variety of ecology systems and forests, water, and soil. Land use consisted of collecting wild product, hunting, rice trading, and dependence on non-wood products.

2. Expanding pioneer period (1967-1988): As a result of developing state policy and state promotion of world market accessibility, the community changed its productive pattern from subsistence to trade. Therefore, it expanded its cultivation area to follow state policy and market demand with such crops as chili, tapioca, and pumpkin, all of which depleted the forest. That means a "clear forest, clean jungle" policy of land use was implemented. During this period, the Communist Party of Thailand played an important role in 
forested areas, as they led and controlled every activity in the forest communities and rural villages in forested areas, national parks, and mountains. This approach caused serious conflicts between local governments, including rural villages and forest communities, and the Communist Party. In addition, the Bru community in Phu Phan National Park was told that they were out-of-control and thus could no longer manage themselves, but instead had to be managed by the central government. This village subsequently joined the Communist Party as guerrillas. After a road was built to the community (1973-1976), the Bru community had access to the market system and returned to managing themselves under the central government again. The central government encouraged this village by supporting them in producing agricultural products for trading, such as tapioca, rice, and sugarcane; and the government gave them more money. This changed land use patterns to favor a new economic system. However, it also decreased natural resources and destroyed many of the forested areas.

3. Community adjustment to varying uses of land (1974-present): The government has controlled community resources and developmental projects, such as the forest orchard project, and national park expansion project. All projects were set up according to a central plan from the government with no participation from the local communities. This situation gave rise to conflicts between local communities and the central government. Finally, the government had to cancel those projects and instead started land allocation for survival to the original land owners. From this project came conflict between the people in local communities because they were all fighting to be owners of land in forested areas. However, this situation made people gain new experiences in order to manage natural resources together, and it also led to new learning among networks of farmers, as well as to the expansion of crops, such as tapioca, sugarcane, fruit, trees, and silk. In addition, they are setting up groups to manage all activities - such as occupational groups, agricultural groups, and groups for preserving the community forest - and are becoming more active in rubber planting. This network can lead people to expand planting areas rapidly and cause the proportion of highland rice fields, tapioca, and other plant fields to increase. Therefore, because of knowledge sharing, network sharing can lead to good management and development of land use, including preserved forests, sacred forests, community forests, forest temple forests, water resources, plant fields, and orchards. In addition, during this period, the Phu Thai ethnic community is adjusting rapidly; therefore, the Phu Thai community can gain benefit from this development more than other ethnic communities can. It has become a prototypical community for rubber planting, has established strong cooperation, and can negotiate prices with the market system.

Internal and external factors affected community management. Internal factors were:

1. community vision of nature

2. social and cultural changes

3. intra-community relationship

4. natural varieties

5. geo-ecological differences

6. group leadership status and group management committee

7. collaboration among community members

8. population increase and community expansion

9. promotion of learning

10. access to technology and innovation

External factors were:

1. state policy, promotion, law, and government rules

2. organization and state policy

3. influence of market system

4. capital system, market system, and accessibility

5. acceptance and support from outside

6. development trends

7. new technology and innovation

8. ability to receive, communicate, and gain information 
9. $\quad$ expansion of the market and capital system

The pattern of collaboration for sustainable community management is:

1. Thinking system: This system provides high value of nature, sacrificing to nature, respect for naturalism, respect for "ghost" as caretaker, and behavioral controller, using nature, being moral toward nature, and respect for natural fairness.

2. Production pattern: Communities must focus on their core competencies in terms of production. In addition, communities must learn more about external factors and about the economic environment in order to plan their production. Also, forest communities must use simple technology, employ low cost production, and avoid negative effects on the environment. In addition, communities must produce several products in order to spread the risk of production, employing price variance and gains in production each year, which will cause increased income.

3. Land use management pattern: Communities must choose an appropriate productive activity and clarify or divide plots into growing plots, water sourcing plots, and reserved plots, and communities should reserve land for forest area not less than 40 percent.

Table 1: Land Use in Thai-Lao Community, Phu Thai Community, and Bru Community

\begin{tabular}{|c|c|c|c|c|c|}
\hline \multicolumn{2}{|c|}{ Thai-Lao community(Sangkaew) } & \multicolumn{2}{|c|}{ Phu Thai community (Nongwaeng) } & \multicolumn{2}{|c|}{ Bru community (Pungdaeng) } \\
\hline Typical & Land use (rai) & Typical & Land use (rai) & Typical & Land use (rai) \\
\hline Irrigating canal & 8 & Road & 167 & Road & 113 \\
\hline Road & 67 & Rice field & 3,614 & Rice field & 1,259 \\
\hline Rice field & 948 & Well in rice field & 82 & Well in rice field & 4 \\
\hline Well in rice field & 8 & $\begin{array}{l}\text { Owner/Community } \\
\text { family forest }\end{array}$ & 1,843 & $\begin{array}{l}\text { Community } \\
\text { family forest }\end{array}$ & 2,410 \\
\hline Cemetery & 10 & Cemetery & 25 & $\begin{array}{l}\text { Owner/ } \\
\text { Reserved forest/ } \\
\text { National forest/ }\end{array}$ & 19,299 \\
\hline $\begin{array}{l}\text { Owner/Community } \\
\text { family forest }\end{array}$ & 137 & $\begin{array}{l}\text { reserved forest/ } \\
\text { National park }\end{array}$ & 6,317 & Mixed orchard & 4 \\
\hline Sacred forest & 12 & Mixed Plant farm & 1,363 & Tomato & 14 \\
\hline $\begin{array}{l}\text { reserved forest/ } \\
\text { National park }\end{array}$ & 11,912 & Mixed orchard & 232 & Topioka & 2,318 \\
\hline Mixed orchard & 22 & Empty space & 5 & Rubber & 2,269 \\
\hline Reservoir & 22 & Topioka & 1,969 & Creek & 354 \\
\hline Topioka & 2,212 & Mixed fruit & 28 & Temple & 41 \\
\hline Mixed fruit & 242 & Rubber & 3,616 & Swamp/pond & 18 \\
\hline Rubber & 1,658 & Creek & 186 & Village & 216 \\
\hline Eucalyptus & 95 & Temple & 18 & Sugar cane & 59 \\
\hline Creek & 1,182 & Chilly orchard & 16 & & \\
\hline Temple & 16 & Teak garden & 248 & & \\
\hline Rattan farm & 7 & Herb garden & 9 & & \\
\hline Swamp/pond & 1 & Rattan farm & 2 & & \\
\hline silk & 45 & Swamp/pond & 103 & & \\
\hline Village & 202 & Village & 226 & & \\
\hline Sugar cane & 127 & Sugar cane & 43 & & \\
\hline Total & 18,933 & Total & 20,112 & Total & 28,378 \\
\hline
\end{tabular}

\section{DISCUSSION AND CONCLUSION}

Land use in Phu Phan has been continuously changing, adapting, and adjusting for five decades. The study found that land use patterns in each period are significantly different from region to region; however, the main 
productive activity pattern is similar. Even if it is influenced by the state system and world system, the community would be able to adapt and survive.

Seajantra (1998) found that geographical context was the main factor in the differences of productive system and agricultural land used. However, we found that the differences, similarities, or combinations of land use patterns are social and cultural and that outside forces were state policy and market accessibility influenced to land use than eco-nature. That means the geomorphology was different, but the productive activity in land use was similar.

Finally, based on our study, we recommend that government must establish new public policy to support particular ethic communities in forest areas:

1. Policy of ecology management with local community: This policy is means that the central government must decentralize their authority and leave decisions to local communities in forest areas with a public opinion strategy. In addition, local communities can participate in every activity and every public policy that will affect them.

2. Knowledge sharing policy: This policy is means that government agencies must ask local people to share ideas about how to develop in that area and establish policy and development activities together.

3. Policy for the management of the river basin: Water is the heart of life, so government agencies should provide knowledge on how a forest, river, and community can live together, by informing the people about the conservation concept of forest, land, soil, and river. The government should also budget funds to continue to support these activities.

4. Decentralization policy: The central government must decentralize its authority toward local administrations, such as municipalities and sub-district administrations, to encourage local cooperation in forest management for solving the problems of natural resource management.

We hope that our suggestions and recommendations provide guidelines and knowledge to government agencies, with similar problems to those in Thailand, for establishing the right policy for natural resource management.

\section{ACKNOWLEDGEMENTS}

We would like to express our gratitude to Multi Maekhong sub-region Research Center for its research financial support, and we also acknowledge with appreciation Dr.Thongphon Promsaka Na Sakolnakorn for the helpful suggestions and comments for this article. Finally, we would like to thank the villagers of Thai-Lao ethnic community in Srangkaew village, Phu Thai ethnic community in Nongwang village, and Bru ethnic community in Pung Daeng village for their helpful information.

\section{AUTHOR INFORMATION}

Prasit Kunurat (M.Ed. in Geography, Cert. Manager Management A.I.M.), Tai Studies Programs, Associate Professor in Geography, Faculty of Humanities and Social Sciences, Mahasarakham University, Thailand.

Preecha Piampongsarn, Ph.D. (Political Economy, Hamburg University, Germany), Faculty of Economy, Chulalongkorn University, Thailand.

Preecha Prathepa, Associate Professor, Ph.D. (Botanical), Walairukhavej Botanical Research Institute, Mahasarakham University, Thailand.

Boonyong Ketthed, Associate Professor, Ph.D. (Anthropology), Faculty of Humanities and Social Sciences, Mahasarakham University, Thailand. 


\section{REFERENCES}

1. Arrouays, D., Daroussin, J., Kicin, J.L., Hassika, P., 1998. Improving topsoil carbon storage prediction using a digital elevation model in temperate forest soils of France. Soil Science, 163: 103-108.

2. Bush, G., 2006. Future European agricultural landscapes - what can we learn from existing quantitative land use scenario studies. Agric. Ecosyst. Environ, 114 (1): 121-140.

3. De Groot, R., 2006. Function analysis and valuation as a tool to assess land use conflicts in planning for sustainable multifunctional landscapes. Landscape Urban Plan, 75 (3-4): 175-186.

4. Gallardo, A., 2003. Spatial variability of soil properties in a floodplain in Northwest Spain. Ecosystems, 6(6): 564-576.

5. Ganjanapan, A. 1987. Conflicting Pattern of Land Tenure among Ethnic Group in Highlands of Northern Thailand : The Impact of State and Market Intervention, Proceeding of the International Conference on Thai Studies, Australia National University, Canberra, Australia.

6. 2000. Local control of land and forest: Cultural dimensions of resource management in Northern Thailand. Chiang Mai : Regional Center for Social Science and Sustainable Development.

7. Hairston, A.B., Grigal, D.F., 1991. Topographic influences on soil and trees within single mapping units on a sandy outwash landscape. Forest Ecology and Management, 43: 35-45.

8. Haque, F. 1985. The changing face of forest industry. Food and Agriculture Organization of The United Nation. Report paper Issue number: 153: R9400/E.

9. KeBler, C. 1998. Community Forestry in Thailand. The World Bank: WBI's CBNRM Initiative.

11. Kline, J., Wichelns, D., 1996. Measuring public preferences for the environmental amenities provided by farmland. European Review of Agricultural Economics,. 23-4, 412-436.

12. Myers, R. L. 2005. The Isan SAGA: The Inhabitants of Rural Northeast Thailand andtheir Struggle for Identity, Equality and Acceptance (1964-2004), San Diego State University.

13. Mottet, A., Ladet, S., Coque, N., Gibon, A., 2006. Agricultural land-use change an its drivers in mountain landscapes: a case study in the Pyrennees. Agric. Ecosyst.Environ. 114 (2-4), 296-310.

14. Rojanapraiwong, S. 1999. Environmental Status in Thailand 1997-1998. Bangkok: Amarin Printing.

15. Seajantra, T. 1998. Transformations du System Agaire de Thung Look Nok (Plain Centrale) at Perspectives de l'Agriculture Thailand. Paris:Grignon.

16. Westhoek, H.J., Van den Berg, M., Bakkes, J.A., 2006. Scenario development to explore the future of Europe's rural areas. Agric. Ecosyst. Environ. 114 (1), 7-20. 
NOTES 